\title{
Understanding how access shapes the transformation of ecosystem services to human well-being with an example from Costa Rica
}

\author{
Marta Berbés-Blázquez ${ }^{a, b, *}$, Martin J. Bunch ${ }^{a}$, Peter R. Mulvihill ${ }^{a}$, Garry D. Peterson ${ }^{\text {, }}$, \\ Berna van Wendel de Joode ${ }^{\mathrm{b}}$
}

${ }^{a}$ York University, Faculty of Environmental Studies, 4700 Keele St, Toronto, Ontario M3J 1P3, Canada

${ }^{\mathrm{b}}$ Central American Institute for Studies on Toxic Substances (IRET), Universidad Nacional, Heredia 86-3000, Costa Rica

${ }^{\text {c } S t o c k h o l m ~ R e s i l i e n c e ~ C e n t r e, ~ S t o c k h o l m ~ U n i v e r s i t y, ~ K r a ̈ f t r i k e t ~ 2 B, ~ S E-106 ~} 91$ Stockholm, Sweden

\section{A R T I C L E I N F O}

\section{Article history:}

Received 30 September 2016

Received in revised form 11 September

2017

Accepted 25 September 2017

Available online 26 October 2017

\begin{abstract}
A B S T R A C T
Increasingly, ecosystem services have been applied to guide poverty alleviation and sustainable development in resource-dependent communities. Yet, questions of access, which are paramount in determining benefits from the production of ecosystem services, remain theoretically underdeveloped. That is, ecosystem assessments typically have paid little attention to identifying real or hypothetical beneficiaries and the mechanisms by which benefits may be realized. This limits their ability to guide policy and interventions at the local scale. Through a qualitative mixed methods approach, this article analyzes how access to different aspects of the production of provisioning services is negotiated in Bribri communities (Costa Rica) of small-scale plantain farmers with alternative modes of agricultural production. The analysis considers access to land, labour, knowledge, tools, markets, and credit. Our analysis reveals how institutions of access are organized differently in traditional vs. conventional systems of agriculture and how these shape power dynamics and pathways to well-being. We conclude that understanding institutions regulating access to ecosystem services provides more useful insights for poverty alleviation than approaches that assume homogeneous access to benefits.
\end{abstract}

(c) 2017 Elsevier B.V. All rights reserved.

\section{Introduction}

The concept of ecosystem services is increasingly used to understand and improve human well-being in resourcedependent communities. However, in communities where livelihoods are closely tied to a dominant provisioning ecosystem service - such as those communities that produce plantain, soya, or fish as commodities - there appears to be a disconnect: despite high yields of provisioning services, many communities face significant socio-economic challenges (e.g. Béné, 2003). The disparity between producing ecosystem services and attaining a good standard of living opens a fundamental question about how residents in resource-dependent communities access the benefits of ecosystem services, which are often assumed to flow automatically (Nahlik et al., 2012). In this article, we take a closer look at the question of access in resource communities in Costa Rica, paying particular attention to how local beneficiaries experience and

* Corresponding author at: Arizona State University, Julie Ann Wrigley Global Institute of Sustainability, PO Box 875402, Tempe, AZ 85287-5402, United States.

E-mail addresses: mberbes@gmail.com (M. Berbés-Blázquez), bunchmj@ yorku.ca (M.J. Bunch), prm@yorku.ca (P.R. Mulvihill), garry.peterson@su.se (G.D. Peterson), berendina.vanwendel.dejoode@una.cr (B. van Wendel de Joode). negotiate the relationship between ecosystem services and human well-being.

Large-scale, aggregate assessments of ecosystem services are limited in their ability to guide policy and interventions at the local scale, especially in development settings where there exist complex linkages between poverty, vulnerability and ecosystems. The assumption that increases in the output of ecosystem services correspond to increases in human well-being simply does not hold, at least not in any straightforward manner. Indeed, the conclusions of the MA (2005) indicate that human well-being increased globally at the same time as the majority of ecosystem services around the world declined (Raudsepp-Hearne et al., 2010), and it is possible to have the supply of ecosystem services increase at the expense of the well-being of particular groups in society (Daw et al., 2015). Indeed, several critiques have called for more nuanced understanding of the complexities associated with the distribution of benefits and the role of trade-offs (see Daw et al., 2011, 2015; Fisher et al., 2013; Bennett et al., 2015; Felipe-Lucia et al., 2015; van Hecken et al., 2015; Berbés-Blázquez et al., 2016; Wieland et al., 2016).

Alternative conceptualizations of ecosystem services have defined them as the elements of ecosystems that support human 
well-being without constituting benefits by themselves (Daily, 1997; de Groot et al., 2002). Many of these conceptualizations depict ecosystem services as cascades to emphasize the intermediary steps between an ecosystem's biophysical processes and the eventual improvement in human well-being (e.g. de Groot et al., 2010; Potschin and Haines-Young, 2011). Each step in the cascade represents a social-ecological transformation, which grants an opportunity to examine additional factors mediating the relationship between ecosystems and well-being. Among the many factors that play a role in shaping the successive transformations, access has a crucial impact on how stakeholders experience ecosystem services (Daw et al., 2011; Hicks and Cinner, 2014).

In this paper, we focus on institutions that regulate access to ecosystem services as key elements in the process of actualizing human well-being in resource-dependent communities. Our analysis compares the organization of access in indigenous Bribri communities that produce plantain in Costa Rica. Farmers in the Bribri Territory provide an interesting case study because two agricultural systems of small-scale farming co-exist, one based on traditional practices, the other based on conventional practices. While both systems produce the same provisioning ecosystem service, i.e. plantains, the institutional organization of access differs, thus creating an opportunity for comparison. The rest of the paper is organized as follows: In the next section, we introduce a framework for analyzing access applicable to ecosystem services; we then describe our methods and the research site in the Bribri Territory before launching into the details of how access is organized using the small-scale production of plantain as an example of a provisioning ecosystem service; we finish with a discussion of the implications of access in our understanding of ecosystem services and further applicability of this framework.

\section{Access}

This paper focuses on the institutions that mediate access in the production of ecosystem services. We define institutions broadly as the regularized patterns of behaviour among groups and individuals in society (after Leach et al., 1999), and access as all the possible mechanisms by which a person is able to benefit from things (after Ribot and Peluso, 2003). The ecosystem services cascades aforementioned generally distinguish between the following transformations (Fig. 1): 1) An initial transformation of the biophysical flows of an ecosystem into an ecosystem service. This transformation is mediated by a system of production that includes capital, technology packages and labour. Similar provisioning ecosystem services can be obtained following different production processes, for instance, a crop can be industrially farmed using agrochemicals and migrant labourers or it can be farmed organically in smallholdings by members of a single household. 2) In the second transformation, the ecosystem service becomes a benefit to someone. A single ecosystem service can produce an array of benefits for different stakeholders. For instance, those who consume the crop will gain nutrition, while those who sell the crop will obtain an economic gain. 3) A third transformation concerns how human well-being is impacted by a given ecosystem benefit depending on the personal circumstances of individuals or groups. Factors such as health, gender, or culture, shape how people enjoy ecosystem services, e.g. flour may provide nutrients to one person and cause an allergic reaction to another one. This is very much in line with understandings of well-being based on Sen's capabilities approach (Sen, 1988, 1999). Sen's approach to development deemphasized utilitarian ideas of well-being and highlighted instead the diversity of contexts and human experiences (Forsyth, 2015). Thus, Sen posited that improving well-being depended on removing the obstacles that stood on the way of expanding people's freedom to achieve what they value being or doing (Deneulin and Shahani, 2009).

Access barriers may exist at each step of the ecosystem service cascade as illustrated in Fig. 2. Although this is generally acknowledged, there is a dearth of empirical work and a lack of methodologies applicable to characterizing access. Notable exceptions are Daw et al. (2011) and Hicks and Cinner (2014) who conducted analyses where they disaggregated the recipients of ecosystem benefits living in coastal communities in the Indian Ocean into distinct stakeholder groups. Thus, empirical research to date has focused mainly on the last step of the cascade (step 3 in Fig. 2) to understand how the positionality of different actors shapes the way in which they experience ecosystem services.

Our article is complementary to previous efforts to characterize access but it focuses on access with regards to the system of production applied to obtaining an ecosystem service and its corresponding socio-economic organization that oversees the distribution of the benefits and impacts of that service. Our analysis uses Ribot (1998) and Ribot and Peluso (2003) whose analytical framework suggests thinking of access as a bundle made up of interwoven strands that together create the 'web of benefits' experienced by an individual or a group at a given time. Some of the strands that are essential for ecosystem services include having access to: land, tools and technology, capital and credit, markets, knowledge and information, and labour opportunities. We use these categories to guide the analysis of the Bribri agricultural social-ecological system. Our work considers the mechanisms used by farmers to gain, maintain and control access to these aspects of production where, maintaining access refers to the efforts dedicated to keeping a particular benefit; gaining access, refers to the initial process by which access is established; and controlling access refers to the ability to regulate other people's access. The analysis of access is presented as a comparison between the traditional and the conventional farming systems that co-exist in the Bribri Territory.

\section{Methods}

A number of methods can be used to obtain information that answers the following questions with respect to the systems for ecosystem service production and distribution:

1. Who controls access to the land (or sea, in the case of fisheries)?

2. Who controls access to the knowledge and information required to produce an ecosystem service (e.g. best cropping practices or reliable weather information)?

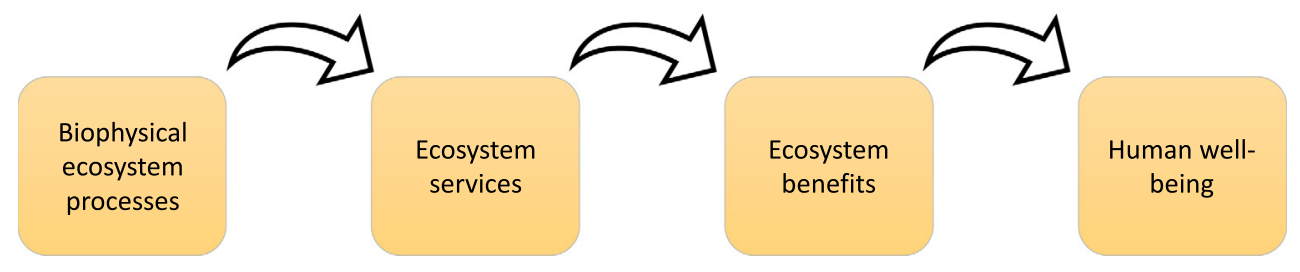

Fig. 1. An ecosystem services cascade. 


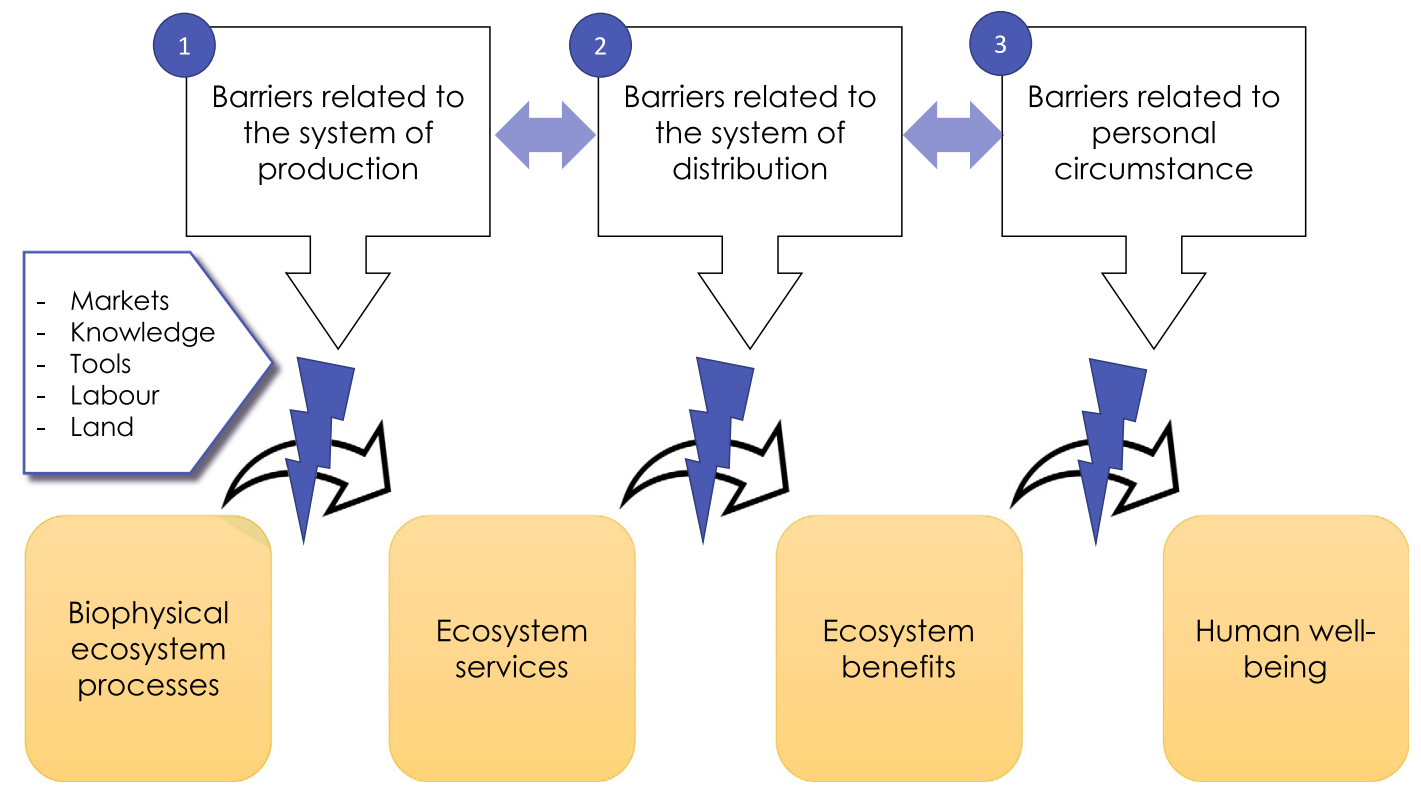

Fig. 2. Possible barriers of access in the ecosystem service cascade.

3. Who controls access to the tools and the technology associated to the production of ecosystem services (e.g. agrochemicals, seeds or farming utensils)?

4. Who controls access to markets to commercialize provisioning ecosystem services (e.g. local farmer's markets, co-operatives, or food retailers)?

5. Who is able to labour or has access to labourers to work in the production of ecosystem services?

Without being prescriptive, adequate methods to answer the above questions may include participant and/or field observations (Mason, 2009; DeWalt and DeWalt, 2011), qualitative interviews (Kvale, 1996; Kvale and Brinkmann, 2009), surveys, review of secondary sources, ethnographic approaches (Atkinson et al., 2001) and mixed methods approaches.

Our analysis is supported by a review of secondary sources from the peer review literature combined with field observations. Field observations encompass a variety of techniques with the idea of immersing oneself in a research setting to experience and observe first hand a range of dimensions pertinent to that setting (Mason, 2009). Observable events include people's daily routines, interactions, relationships, norms, spatial arrangements and so on. Field observations deliver nuanced and complex data that is difficult or impossible to capture otherwise (Mason, 2009). It also allows the researcher to draw on their own lived experience of the place while being aware of their position as outsiders to the community. In this case, field observations were conducted through several short stays (1-2 weeks at a time) in the communities of Suretka, Shiroles and Amubrë between June and November 2012. Typical community spaces that were visited during these stays included grocery stores, family restaurants, agricultural farms, cooperatives, sport events, and people's homes. Notes and personal reflections were recorded daily while in the field and insights from these inform the analysis below.

\section{Research site: The Bribri Indigenous Territory}

Our analysis of access considered communities in the Bribri Indigenous Territory situated in the Talamanca county in the South-Atlantic coast of Costa Rica and one of the poorest regions of Costa Rica. The Bribri Indigenous Territory was recognized in
1977 as a result of the passing of the Costa Rican Indigenous Law. The territory spans $437 \mathrm{~km}^{2}$ and has a population of approximately 8500 residents. The Bribri Indigenous Territory is governed by a local Indigenous government known as the Indigenous Bribri Association for the Integrated Development of Talamanca (ADITIBRI, Spanish acronym). Our study focuses on the communities of Lower Talamanca, primarily Suretka, Shiroles and Amubrë, which encompasses the areas below 500 meters above sea level (Fig. 3). The Talamanca county supplies over half of the plantain production of Costa Rica (Municipality of Talamanca, 2003). Plantains from the Talamanca region are sold to both national and international markets although we focus here solely on the former. To sell nationally, Bribri farmers bring their harvest to a sales point in Suretka for middlemen to purchase and transport to the central depot in the capital city of San Jose (5-6 hours away by road) where large- and medium-size food retailers purchase the fruit. Middlemen are outsiders to the territory and they are generally nonIndigenous.

There is a mix of traditional and more intensive forms of agriculture in Talamanca. For the purposes of this paper we follow the definitions of FAO (2009) where the term "conventional agriculture" refers to agriculture characterized by monocultures, mechanization and the use of agrochemicals, and the term "traditional agriculture" refers to indigenous forms of farming, usually as diversified agricultural systems that rely on local knowledge and non-synthetic inputs. Two examples of what these agricultural systems look like in the Bribri Indigenous Territory are shown in Fig. 4.

\section{Access in the Bribri Territory social-ecological system}

\subsection{Land}

Access to land in the Bribri Territory is regulated by Costa Rican Indigenous Law, which states that Indigenous reserves are "nontransferable and exclusive for the indigenous communities living on them". Furthermore, all of the land of the territory is registered under the name of the local Indigenous government, ADITIBRI, which subsequently grants residents access to plots of land. Decisions about land-use are taken at the household level. Initial access to the land is therefore gained either through matrilineal inheritance or through purchase between Indigenous residents. 


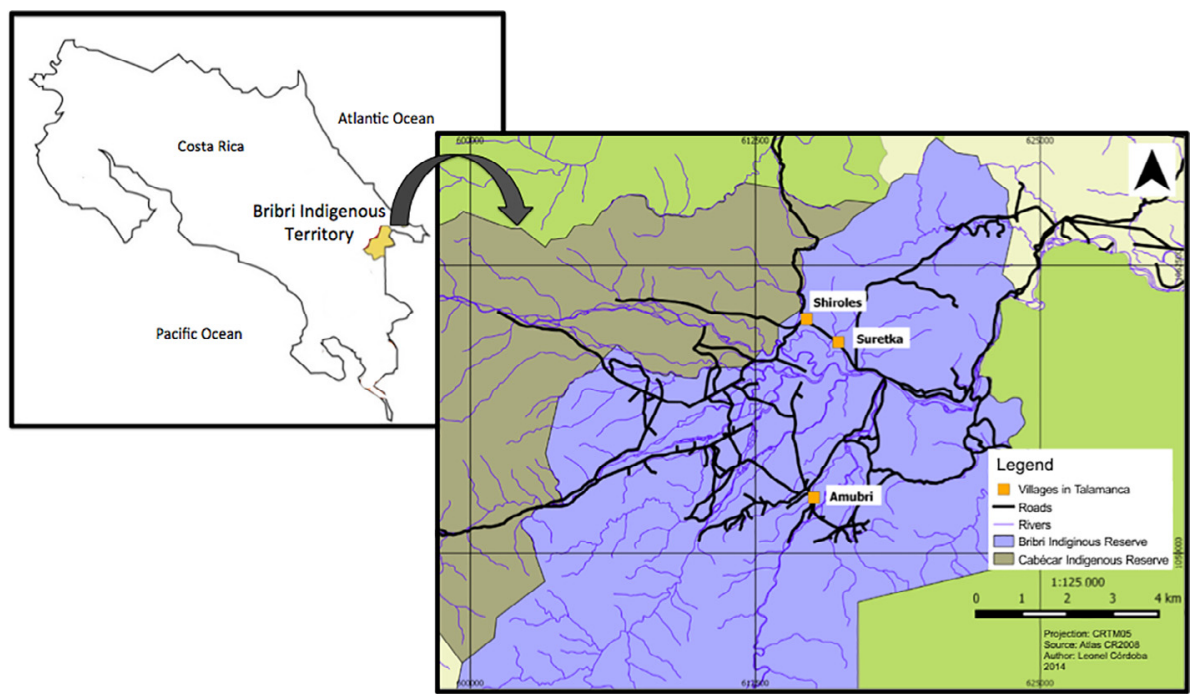

Fig. 3. Research sites in the Bribri Indigenous Territory (Costa Rica). Source: Leonel Cordoba, with permission.

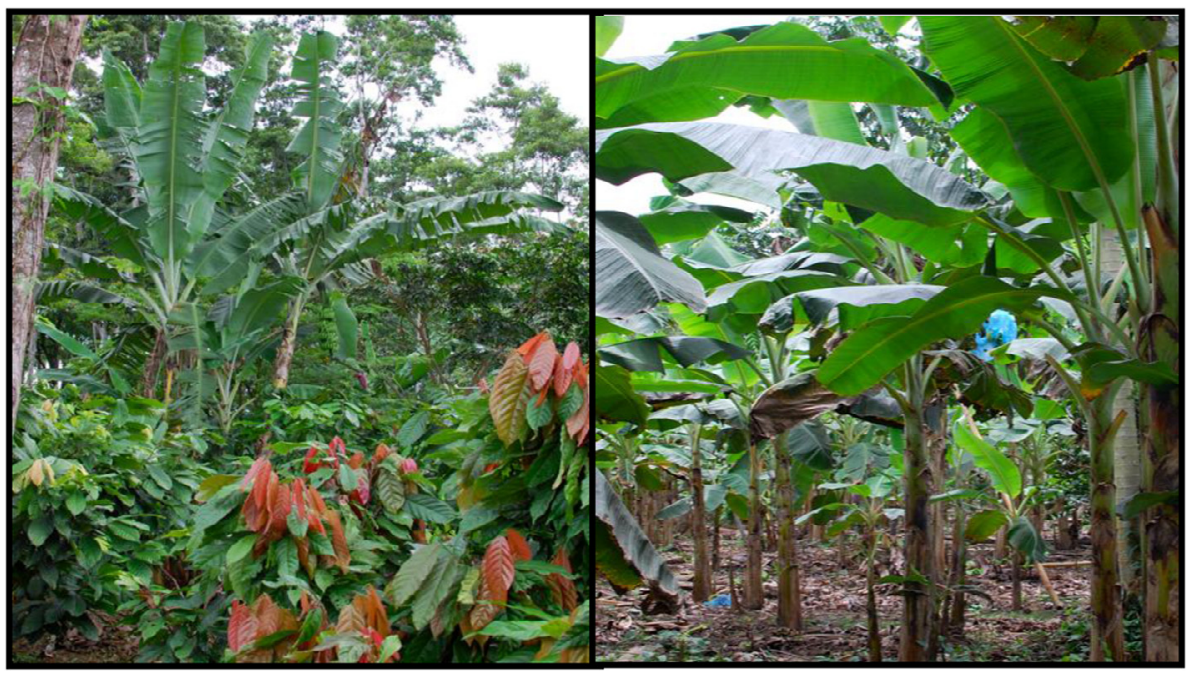

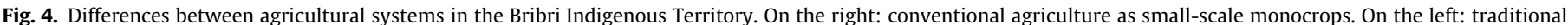
agriculture combining plantains, cocoa, fruit trees and other species. Source: Berbés-Blázquez.

In terms of maintaining access to land, residents are protected by Costa Rican Indigenous Law, which stipulates that Indigenous people can negotiate and transfer land only among themselves. Yet, approximately 35 percent of the land in the Bribri Territory is currently in non-indigenous hands, particularly around the more accessible communities of Shiroles and Suretka (Guevara-Viquez, 2011). Rapid population growth in Talamanca presents an additional challenge to maintaining access to land. In some cases, growth has reduced the size of family plots to the point where subsistence and commercial agriculture have become unviable.

\subsection{Tools and technology}

The upkeep of plantains requires cleaning debris at the base, deleafing, removing suckers and rotted stems, weeding and pest control (Robinson and Saúco, 2010). In the traditional system, plantain maintenance is conducted using manual labour and simple tools, such as machetes. Pests are controlled by managing shade to prevent their proliferation, which means pruning and interspersing tree species of varying heights (Polidoro et al., 2008). Some farmers use vegetable-based insecticides made out of sandbox tree sap. By and large, all of these activities involve simple, affordable tools that farmers are able to purchase and know how to use. Hence, it is relatively easy for farmers to gain, control and maintain access to the tools and technologies needed in traditional agriculture.

Conventional plantain farming involves additional tools to deal with pests that proliferate in monocrops. The cost of an agrochemical often determines the extent to which it is used. For instance, fungicides used to combat black Sigatoka are expensive, hence, they might be applied sparingly. Chlorpyrifos-coated bags are used by $98 \%$ of conventional farmers (Polidoro et al., 2008). Chlorpyrifos protects the fruit against thrips but more importantly, the bag keeps the peel of the plantain looking lighter and free of black spots. While this is purely aesthetic, middlemen pay more for plantains that come in the bags (sometimes twice as much), giving a strong incentive for farmers to switch to conventional practices. At the same time, the cost of additional fertilizers and agrochemicals is an entry barrier for many indigenous farmers. While this presents a barrier to obtaining initial access to the tools and the technology necessary for conventional agriculture, middlemen 
are eager to finance the switch in exchange for the farmer's harvest (more on this later).

\subsection{Knowledge and information}

Traditional agriculture is based on knowledge that is codified within a set of cultural practices that regulates which plants and animals can be harvested and when (Rojas-Conejo, 2002; GarcíaSerrano and Del Monte, 2004). Some of this information is common enough that a person living in the territory might encounter it throughout their upbringing. More sophisticated information might be the purview of certain individuals, such as elders (awapas) and healers (sikuas), or of specific clans that are the keepers of certain knowledge. Gaining and maintaining access to this information involves partaking in cultural rituals and fulfilling prescribed roles. However, since colonization, external pressures have undermined Bribri cultural beliefs significantly. The push towards economic integration and the change in lifestyle is evident across generational lines. This means that traditional knowledge could become eventually inaccessible to future generations.

Conventional plantain agriculture requires knowledge and information on agrochemical pest-control. Indigenous farmers are generally not well versed on the use of agrochemicals (Polidoro et al., 2008; Barraza et al., 2011) unless they have had previous experience working in large-scale plantations outside of the territory. Hence, most conventional Bribri farmers rely on middlemen to access information about agricultural practices. However, the advice dispensed by middlemen is based on commercial requirements for the sale of the plantains rather than on best farming practices. For instance, the insistence on the use of chlorpyrifos-coated bags responds not so much to the need for pest control but to keep the plantain peels looking lighter and more appealing to consumers.

\subsection{Markets}

Given their remoteness, Bribri producers who want to sell in the national market have little choice but to sell through the middlemen. Therefore, middlemen control access to the market by controlling the transportation route. Farmers who sell to middlemen have an incentive to switch to conventional agricultural practices because conventional plantain sells at a higher price. Having few buyers relative to the number of sellers gives middlemen an undue advantage to determine the sale price. Yet, bypassing the middlemen to gain access to the national market is next to impossible for indigenous producers because middlemen and retailers in the central depot in San Jose maintain a tight system of reciprocal loyalties. What maintains these loyalties is a combination of long-standing relations, the possibility of monitoring each other (i.e. a retailer would know if a middleman sold the plantain to someone else and vice versa), and likely some degree of prejudice against indigenous peoples (Christian, 2013).

In an attempt to gain access to alternative markets, and to better prices, Bribri farmers began organizing into cooperatives in the 1990s. Cooperatives were set up by producers who practiced traditional agriculture to sell bananas, plantains and cocoa destined to international markets for retailers of organic and fairtrade products. Access to the international market depends on the viability of the cooperatives themselves. Whereas some cooperatives have been operating for years, many cooperatives have dissolved in part due to predatory pricing, as middlemen increase their purchase price temporarily to draw farmers away from the cooperative.

\subsection{Capital and credit}

Residents of the Bribri Territory cannot access credit from Costa Rican financial institutions because they are unable to provide a land title as collateral. This is a consequence of the status of the region as an Indigenous reservation. Given this situation, middlemen act as a source of informal credit to finance the switch to conventional agriculture in exchange for the farmers' harvest (Whelan, 2005). There are no official records on the amount of informal lending or interest rates, but Dahlquist et al. (2007) determined that $26 \%$ of the households in the territory received credit from plantain middlemen. This percentage increased to $53 \%$ for households in the more accessible parts of the territory such as the communities of Suretka and Shiroles. It is unclear whether there exist other informal credit systems, such as loans from family, peer-to-peer lending or micro-credit schemes in the territory.

\subsection{Labour}

Plantain farms are family-run operations where over $90 \%$ of the producers rely on the work of their household members to tend to the production (Orozco et al., 2008). The remaining 10\% of producers hire day-workers, especially for tasks that are physically demanding or unpleasant, such as spraying pesticides (Orozco et al., 2008). While, in theory, the majority of farmers can easily gain and control access to labour; in practice, it can be difficult to secure reliable labour. Day-workers tend to be the young and landless who, for the most part, are not interested in pursuing the farming lifestyle and would prefer to work outside of the territory, especially in the ballooning ecotourism industry. Even when youth are interested in agriculture, producers indicated that state institutions, such as the National Child Welfare Board may interfere with their ability to involve their own children in agricultural activities. In-kind exchanges are part of the traditional practices but are becoming less common. These practices include the mano vuelta (literally 'returned hand'), where two people agree to help one another, and chichadas, where a large job is done collectively and everyone gets invited to drink chicha (an alcoholic drink) afterwards. These transactions involve no exchange of money and are less structured than a formal job, e.g. a person might come to help one day, but the next day goes to help someone else.

\subsection{Summary of access}

The organization of access in the conventional and the traditional systems of agriculture in the Bribri Territory is different with respect to the number of actors who control the access of others (Table 1). Actors who have the ability to control aspects of provisioning ecosystem service production may be thought as gatekeepers. We note that in the conventional system middlemen are the main gatekeepers regulating access to most aspects of plantain production. The two exceptions are access to land, which is defined by Costa Rican law and locally managed by the local indigenous government, and decisions about hiring labour that are relegated to the household sphere. By contrast, in the traditional system there is a wider group of actors that behave as gatekeepers controlling the different aspects of ecosystem service production.

\section{Discussion}

Using the Bribri case study, we note that although both traditional and conventional farmers produce plantains, each method of production is mediated by alternative institutional arrangements with respect to its organization of access. We highlight several important ways in which the role of access is revealed and the 
Table 1

Dimensions of access in plantain production and corresponding gatekeepers in the traditional and conventional systems of plantain agriculture in the Bribri Territory.

\begin{tabular}{|c|c|c|c|c|}
\hline Dimension & Agricultural System & How is access gained? & How is access maintained? & How is access controlled? \\
\hline Land & Both & $\begin{array}{l}\text { Land is assigned by ADITIBRI, inherited } \\
\text { or sold among Indigenous residents }\end{array}$ & $\begin{array}{l}\text { Through group membership. } \\
\text { Population pressures can reduce } \\
\text { access in the future }\end{array}$ & ADITIBRI controls land distribution \\
\hline \multirow[t]{2}{*}{$\begin{array}{l}\text { Tools and } \\
\text { technology }\end{array}$} & Traditional & $\begin{array}{l}\text { Farmers have access to purchasing } \\
\text { simple tools, e.g. machetes }\end{array}$ & $\begin{array}{l}\text { There is minimal maintenance for } \\
\text { the tools used in traditional } \\
\text { agriculture }\end{array}$ & $\begin{array}{l}\text { Farmers have control over their work } \\
\text { tools }\end{array}$ \\
\hline & Conventional & $\begin{array}{l}\text { Farmers purchase agrochemicals from } \\
\text { middlemen. Cost of agrochemicals is an } \\
\text { entry barrier for some farmers }\end{array}$ & $\begin{array}{l}\text { Continued access depends on } \\
\text { maintaining relationships with } \\
\text { middlemen }\end{array}$ & $\begin{array}{l}\text { Middlemen are the only distributors of } \\
\text { agrochemicals in the territory }\end{array}$ \\
\hline \multirow[t]{2}{*}{$\begin{array}{l}\text { Knowledge and } \\
\text { information }\end{array}$} & Traditional & $\begin{array}{l}\text { Farmers learn from other farmers or } \\
\text { from their family. Some knowledge is } \\
\text { codified in cultural practices }\end{array}$ & $\begin{array}{l}\text { Through group membership. The } \\
\text { changing lifestyle and the presence } \\
\text { of state institutions in the territory } \\
\text { may reduce access to this } \\
\text { knowledge in the future }\end{array}$ & $\begin{array}{l}\text { Specialized knowledge is kept by } \\
\text { specific clans or designated individuals } \\
\text { such as elders and/or healers }\end{array}$ \\
\hline & Conventional & $\begin{array}{l}\text { Middlemen disseminate information } \\
\text { on conventional agricultural practices. } \\
\text { Farmers who have worked outside of } \\
\text { the territory also have pertinent } \\
\text { information }\end{array}$ & $\begin{array}{l}\text { Middlemen and farmers interact on } \\
\text { a regular basis }\end{array}$ & $\begin{array}{l}\text { The remoteness of the territory makes } \\
\text { middlemen one of the few sources of } \\
\text { information }\end{array}$ \\
\hline \multirow[t]{2}{*}{$\begin{array}{l}\text { Markets and } \\
\text { pricing }\end{array}$} & Traditional & $\begin{array}{l}\text { Middlemen come into the territory on } \\
\text { a daily basis to purchase plantains from } \\
\text { traditional farmers. Access to } \\
\text { international markets depends on } \\
\text { cooperative membership }\end{array}$ & $\begin{array}{l}\text { Middlemen and farmers tend to } \\
\text { develop reciprocal relationships and } \\
\text { farmers often sell to the same } \\
\text { middleman over time }\end{array}$ & $\begin{array}{l}\text { The remoteness of the territory makes } \\
\text { it impractical for farmers to go to depot } \\
\text { in the capital. Besides, middlemen and } \\
\text { buyers in the central depot have a } \\
\text { reciprocal system of loyalties }\end{array}$ \\
\hline & Conventional & $\begin{array}{l}\text { Middlemen come into territory on a } \\
\text { daily basis to purchase plantains from } \\
\text { conventional farmers. Conventional } \\
\text { plantain does not sell in international } \\
\text { markets }\end{array}$ & $\begin{array}{l}\text { Farmers are indebted to the } \\
\text { middleman who finances their } \\
\text { switch to conventional agriculture }\end{array}$ & $\begin{array}{l}\text { The remoteness of the territory makes } \\
\text { it impractical for farmers to go to depot } \\
\text { in the capital. Besides, middlemen and } \\
\text { buyers in the central depot have a } \\
\text { reciprocal system of loyalties }\end{array}$ \\
\hline $\begin{array}{l}\text { Capital and } \\
\text { credit }\end{array}$ & Both & $\begin{array}{l}\text { Middlemen loan money to farmers to } \\
\text { cover initial costs of switching to } \\
\text { conventional agriculture }\end{array}$ & $\begin{array}{l}\text { Farmers repay the loan by selling } \\
\text { their crop to a particular middleman }\end{array}$ & $\begin{array}{l}\text { Farmers do not have access to } \\
\text { alternative lending sources because } \\
\text { Bribri residents do not have land titles. } \\
\text { The territory has a single land title } \\
\text { under the name of the local } \\
\text { government }\end{array}$ \\
\hline Labour & Both & $\begin{array}{l}\text { Farmers rely on household members } \\
\text { for farm labour. Some traditional } \\
\text { rituals ensure reciprocity in } \\
\text { exchanging favours }\end{array}$ & $\begin{array}{l}\text { Changing lifestyles in favour of paid } \\
\text { wages threaten the availability of } \\
\text { labour }\end{array}$ & $\begin{array}{l}\text { Farmers control access to labour, } \\
\text { although state institutions control } \\
\text { things such as legal working age }\end{array}$ \\
\hline
\end{tabular}

implications that this has for ecosystem management and the improvement of human well-being in resource-dependent communities:

First, the analysis of access shows how power is distributed among stakeholders. In the Bribri case, we note that the conventional and the traditional systems of plantain agriculture distribute power and influence differently among local actors. In the conventional system, middlemen become key gatekeepers by virtue of controlling access to most aspects of plantain production. Consequently, with the advancement of conventional agriculture in the territory, middlemen gain importance because they are able to determine not only pricing, but also the technology that farmers should use, they become information sources for farming practices, and they provide credit when needed. Hence, conventional agriculture tends to concentrate power in fewer hands, whereas in traditional agriculture power is shared among a wider group of gatekeepers.

Beyond concentrating power, the advancement of conventional agriculture in the Bribri Territory has the effect of extending nonindigenous influences. Gatekeepers in the traditional system, such as elders or the indigenous government, come from the local context and therefore have a common history and cultural background. This contrasts with gatekeepers in the conventional system who are outsiders to the community and predominantly non-indigenous. Given the extent to which people's identities in farming communities are tied to their agricultural practices, a switch in land management practices needs to be understood as having the potential to reshape the identity of individuals in the community. Thus, the current expansion of conventional agricultural practices may be linked to the erosion of indigenous institutions as non-indigenous actors become key gatekeepers.

Second, when ecosystem services are used in the context of poverty alleviation, a black-box characterization of well-being is insufficient in guiding meaningful interventions and could even result in perverse outcomes. While our proposed analysis focuses on barriers at the level of production and distribution, these barriers interact with the personal circumstances of actors (review Fig. 2). Better characterizations of well-being should provide a sense of the contextual details and personal circumstances of actors that influence their ability to benefit from ecosystem services. For instance, the two farming approaches correspond to two forms of approaching and fulfilling well-being needs. The switch to the conventional model is clearly motivated by the higher price that farmers can obtain for the sale of conventional plantains. Hence, one can assume that conventional farmers place a greater emphasis on securing the material dimensions needed for a good life. As well, the switch furthers the integration of the territory into the market economy, which is a desire often expressed by younger residents. On the other hand, traditional farmers see plantain agriculture as satisfying their economic needs to a degree, but their agricultural practices also contribute to other dimensions of their well-being, namely, satisfying their desire to live according 
to their traditions, develop a sense of belonging and maintaining their indigenous identity.

Understanding the logic under which ecosystem users operate is crucial in guiding local level interventions aimed at alleviating poverty and reducing vulnerability. An approach to sustainable development predicated solely on improving yields of provisioning ecosystem services, may not result in livelihood improvements for all local residents. That is, interventions geared at increasing plantain yields through intensification will benefit those farmers who value material wealth over other dimensions of well-being, but it can be counterproductive to those farmers who place a higher value on tradition. The two pathways to building well-being need not be mutually exclusive, e.g. an intervention to obtain better prices for organic plantains can boost material standing while fostering cultural practices. The point remains that a careful consideration of implicit and explicit trade-offs is required to consider differential impacts of policies on groups of local actors.

Third, and related to the previous one, an analysis of access offers an entry point to understand path-dependency in the institutional arrangements that shape the future choices that ecosystem users will face. This is because either agricultural system will set off feedback loops that determine the range of future options that will become available to the communities. For example, we established that farmers who value material welfare are likely to move towards conventional agriculture, this means that, over time, the assets of conventional farmers will come to reflect this choice. That is, the farmer will develop loyalty to certain middlemen that trade on conventional plantain, these farmers will rely more heavily on stores to purchase food staples, and within a few generations conventional farmers may lack the know-how to farm traditionally. The same is true for traditional farmers who respond to an alternative set of incentives. An important consequence is that, while switching back and forth between the two forms of agriculture is possible, it becomes more difficult the longer a system becomes established. Therefore, the switch in agricultural systems should be interpreted as a deeper change in the possibilities and opportunities that will shape the future well-being in the communities.

Fourth, the analysis of access highlights the degree to which ecosystem services are co-produced. In other words, ecosystem services are the product of natural and social processes, yet the importance of human labour provided by farmers, fishers, or ecotourism operators, often goes unaccounted (Kosoy and Corbera, 2010; Gómez-Baggethun and Ruiz-Pérez, 2011; Palomo et al., 2016; Berbés-Blázquez et al., 2016). This omission is important because labour relations shape the dynamics within a social group, especially in resource-dependent communities where productive activities are deeply intertwined with identity and well-being (Bernstein, 2010). Our analysis shows that different institutional arrangements in relation to access can give raise to forms of unequal exchange and exploitation. For example, the ability of middlemen to control access to the national plantain market gives them an opportunity to use predatory pricing practices to their advantage. Hence, when assessing provisioning ecosystem services, it is crucial to consider the form of production alongside the yields.

In thinking of the applicability of this type of analysis, the case of plantain farmers in the Bribri Territory contains insights transferable to communities that share similar characteristics, that is: First, resource-dependent communities where livelihoods depend on the production of provisioning ecosystem services, particularly when there are intermediaries that control access to markets (e.g. Daw et al., 2011; Wamukota et al., 2015; Hicks and Cinner, 2014), or regulating services such as communities trying to benefit from payments for ecosystem services schemes (e.g. Corbera and Brown, 2010; Pascual et al., 2014). Second, populations where there are cultural differences and a history of colonialism or marginalization, such as with Indigenous peoples in many parts of the world (Ramirez-Gomez et al., 2015). Third, communities where there are significant power differentials among stakeholders (e.g. Felipe-Lucia et al., 2015). Fourth, regions undergoing economic and ecological transitions where the likelihood of tradeoffs among stakeholders is high (e.g. McShane et al., 2011; Hartel et al., 2014; Daw et al., 2015).

\section{Conclusion}

Equating ecosystem service production with benefits is true in general, but not very useful in specific cases and places. An analysis of access demonstrates how ecosystem service assessments based on agricultural yields or land use provide important, yet incomplete, information to understand prosperity in resourcedependent communities. We have argued for and presented an analytical approach that can unravel the social-ecological interactions that shape ecosystem use and benefits. In the Costa Rican communities that we studied, the switch from traditional to conventional agriculture concentrated power in the hands of middlemen who, for the most part, were outsiders to the community. Far from uniformly improving human well-being, the production of ecosystem services seemed to boost certain dimensions of well-being, such as economic gain, while undermining others, such as agency or identity. Therefore, our research suggests that an understanding of access to ecosystem services in resource dependent communities can highlight trade-offs between the different dimensions of human well-being.

This article invites reflection on our understanding and depiction of human well-being as applied to ecosystem services, highlighting the importance of institutions that regulate access. By using the theory of access developed by Ribot and Peluso (2003), this paper presented a framework for the study of ecosystem services that can reveal inequality and power dynamics. We believe that our analytical approach could be applied and extended to understand how institutions shape the co-construction of ecosystem services and their benefits in many places, and such analyses could inform development and management practices that fulfill the promise of ecosystem services by broadly enhancing human wellbeing while enhancing the capacity of ecosystems to continue to support humanity.

\section{Acknowledgements}

The authors would like to thank the Bribri communities and the local indigenous government. Staff from the Central American Institute for Studies on Toxic Substances (IRET) provided support while in the field. Heartfelt thanks to Andrea Morales, Gicela Maldonado, Leonel Cordoba, Juan Camilo Cano, Douglas Barraza and Ineke Wesseling. Bill Found offered valuable feedback at different stages of the research process. Financial support for this work was provided by the International Development Research Centre (IDRC-CRDI), York University's Las Nubes Project and the Adrienne Pocock Family.

\section{References}

Atkinson, P., Coffey, A., Delamont, S., Lofland, J., Lofland, L., 2001. Handbook of Ethnography. SAGE Publications, Los Angeles, USA.

Barraza, D. Jansen, K., de Joode, B.V.W. Wesseling C., 2011. Pesticide use in banana and plantain production and risk perception among local actors in Talamanca, Costa Rica. Environ. Res. 111 (5), 708-717.

Béné, C., 2003. When fishery rhymes with poverty: a first step beyond the old paradigm on poverty in small-scale fisheries. World Dev. 31 (6), 949-975.

Bennett, E.M., Cramer, W., Begossi, A., Cundill, G., Díaz, S., Egoh, B.N., Lebel, L., 2015 Linking biodiversity, ecosystem services, and human well-being: three 
challenges for designing research for sustainability. Curr. Opin. Environ. Sustain. $14,76-85$.

Berbés-Blázquez, M., González, J.A., Pascual, U., 2016. Towards an ecosystem services approach that addresses social power relations. Curr. Opin. Environ. Sustain. 19, 134-143.

Bernstein, H., 2010. Class Dynamics of Agrarian Change. Kumarian Press.

Christian, M., 2013. 'Ellipsis Latin America without the downside': racial exceptionalism and global tourism in Costa Rica. Ethnic Racial Stud. 36 (10), 1599-1618.

Corbera, E., Brown, K., 2010. Offsetting benefits? Analyzing access to forest carbon. Environ. Plan. A 42 (7), 1739-1761.

Dahlquist, R.M., Whelan, M., Winowiecki, L., Polidoro, B., Candela, S., Harvey, C.A et al., 2007. Incorporating livelihoods in biodiversity conservation: a case study of cacao agroforestry systems in Talamanca, Costa Rica. Biodiver. Conserv. 16 (8), 2311-2333.

Daily, G., 1997. Nature's Services: Societal Dependence on Natural Ecosystems. Island Press.

Daw, T., Brown, K., Rosendo, S., Pomeroy, R., 2011. Applying the ecosystem services concept to poverty alleviation: the need to disaggregate human well-being. Environ. Conserv. 38 (04), 370-379.

Daw, T.M., Coulthard, S., Cheung, W.W., Brown, K., Abunge, C., Galafassi, D., Munyi, L., 2015. Evaluating taboo trade-offs in ecosystems services and human wellbeing. Proc. Natl. Acad. Sci. 112 (22), 6949-6954.

De Groot, R.S., Wilson, M.A., Boumans, R.M., 2002. A typology for the classification, description and valuation of ecosystem functions, goods and services. Ecol. Econ. 41 (3), 393-408.

De Groot, R.S., Alkemade, R., Braat, L., Hein, L., Willemen, L., 2010. Challenges in integrating the concept of ecosystem services and values in landscape planning, management and decision making. Ecol. Complex. 7 (3), 260-272.

Deneulin, S., Shahani, L., 2009. An Introduction to the Human Development and Capability Approach: Freedom and Agency. IDRC.

DeWalt, K.M., DeWalt, B.R., 2011. Participant Observation: a Guide for Fieldworkers Altamira Press, Toronto, Canada.

Felipe-Lucia, M.R., Martín-López, B., Lavorel, S., Berraquero-Díaz, L., Escalera-Reyes J., Comín, F.A., 2015. Ecosystem services flows: why stakeholders' power relationships matter. PLoS ONE 10 (7), e0132232.

Fisher, J.A., Patenaude, G., Meir, P., Nightingale, A.J., Rounsevell, M.D., Williams, M. Woodhouse, I.H., 2013. Strengthening conceptual foundations: analysing frameworks for ecosystem services and poverty alleviation research. Global Environ. Change 23 (5), 1098-1111.

Forsyth, T., 2015. Ecological functions and functionings: towards a Senian analysis of ecosystem services. Dev. Change 46 (2), 225-246.

García-Serrano, C.R., Del Monte, J.P., 2004. The use of tropical forest (agroecosystems and wild plant harvesting) as a source of food in the Bribri and Cabecar cultures in the Caribbean coast of Costa Rica. Econ. Bot. 58 (1), 5871.

Gómez-Baggethun, E., Ruiz-Pérez, M., 2011. Economic valuation and the commodification of ecosystem services. Prog. Phys. Geogr. 35 (5), 613-628.

Guevara-Viquez, F., 2011. Cronología básica de los pueblos indígenas de Costa Rica: Desde los inicios del siglo XVI hasta el año 2000. Siwa Pako, San Jose, Costa Rica.

Hartel, T., Fischer, J., Câmpeanu, C., Milcu, A.I., Hanspach, J., Fazey, I., 2014. The importance of ecosystem services for rural inhabitants in a changing cultural landscape in Romania. Ecol. Soc. 19 (2), 42.

Hicks, C.C., Cinner, J.E., 2014. Social, institutional, and knowledge mechanisms mediate diverse ecosystem service benefits from coral reefs. Proc. Natl. Acad. Sci. 111 (50), 17791-17796.

Kosoy, N., Corbera, E., 2010. Payments for ecosystem services as commodity fetishism. Ecol. Econ. 69 (6), 1228-1236.

Kvale, S., 1996. InterViews: an introduction to qualitative research interviewing. SAGE, Thousand Oaks, CA, USA.
Kvale, S., Brinkmann, S., 2009. Interviews: learning the craft of qualitative research interviewing. SAGE, Thousand Oaks, CA, USA.

Leach, M., Mearns, R., Scoones, I., 1999. Environmental entitlements: dynamics and institutions in community-based natural resource management. World Dev. 27 (2), 225-247.

Mason, J., 2009. Qualitative researching. SAGE Publications, Thousand Oaks, California.

McShane, T.O., Hirsch, P.D., Trung, T.C., Songorwa, A.N., Kinzig, A., Monteferri, B., Welch-Devine, M., 2011. Hard choices: making trade-offs between biodiversity conservation and human well-being. Biol. Conserv. 144 (3), 966-972.

Millennium Ecosystem Assessment, 2005. Ecosystems and Human Well-being. Island Press, Washington, DC.

Municipality of Talamanca, 2003. Plan local de desarrollo: 2003-2013. Bribri, Talamanca, Costa Rica.

Nahlik, A.M., Kentula, M.E., Fennessy, M.S., Landers, D.H., 2012. Where is the consensus? A proposed foundation for moving ecosystem service concepts into practice. Ecol. Econ. 77, 27-35.

Orozco, L., Villalobos, M., Ortiz, A., Riascos, L., Mendez, J., Sanchez, V., 2008. Las fincas indígenas Bribri y Cabécar de Talamanca, Costa Rica. Agroforestería en Las Américas 46, 14-20.

Palomo, I., Felipe-Lucia, M.R., Bennett, E.M., Martín-López, B., Pascual, U., 2016. Disentangling the pathways and effects of ecosystem service co-production. Adv. Ecol. Res. 54, 245-283.

Pascual, U., Phelps, J., Garmendia, E., Brown, K., Corbera, E., Martin, A., ... Muradian, R., 2014. Social equity matters in payments for ecosystem services. Bioscience.

Polidoro, B.A. Dahlquist, R.M. Castillo, L.E., Morra, M.J., Somarriba, E., Bosque-Pérez, N.A., 2008. Pesticide application practices, pest knowledge, and cost-benefits of plantain production in the Bribri-Cabécar indigenous territories, Costa Rica. Environ. Res. 108 (1), 98-106.

Potschin, M.B., Haines-Young, R.H., 2011. Ecosystem services exploring a geographical perspective. Prog. Phys. Geogr. 35 (5), 575-594.

Ramirez-Gomez, S.O., Torres-Vitolas, C.A., Schreckenberg, K., Honzák, M., CruzGarcia, G.S., Willcock, S., Poppy, G.M., 2015. Analysis of ecosystem services provision in the Colombian Amazon using participatory research and mapping techniques. Ecosyst. Serv. 13, 93-107.

Raudsepp-Hearne, C., Peterson, G.D., Tengö, M., Bennett, E.M., Holland, T., Benessaiah, K., Pfeifer, L., 2010. Untangling the environmentalist's paradox: why is human well-being increasing as ecosystem services degrade? Bioscience 60 (8), 576-589.

Ribot, J.C. 1998. Theorizing access: forest profits along Senegal's charcoal commodity chain. Dev. Change 29 (2), 307-341.

Ribot, J.C., Peluso, N.L., 2003. A theory of access. Rural Sociol. 68 (2), 153-181.

Robinson, J.C., Saúco, V.G., 2010. Bananas and plantains. CABI, Massachusetts, USA.

Rojas-Conejo, D., 2002. El conflicto entre tradición y modernidad: Constitución de la identidad cultural indígena Bribri. FLACSO, San Jose, Costa Rica.

Sen, A., 1988. The standard of living. Cambridge University Press.

Sen, A., 1999. Development as freedom. Oxford University Press.

Van Hecken, G., Bastiaensen, J., Windey, C., 2015. Towards a power-sensitive and socially-informed analysis of payments for ecosystem services (PES): addressing the gaps in the current debate. Ecol. Econ. 120, 117-125.

Wamukota, A.W., Crona, B., Osuka, K., Daw, T.M., 2015. The importance of selected individual characteristics in determining market prices for fishers and traders in kenyan small-scale fisheries. Soc. Nat. Resour. 28 (9), 959-974.

Whelan, M.P., 2005. Reading the Talamanca Landscape: Land use and Livelihoods in the Bribri and Cabécar Indigenous Territories, (unpublished thesis).

Wieland, R., Ravensbergen, S., Gregr, E.J., Satterfield, T., Chan, K.M., 2016. Debunking trickle-down ecosystem services: the fallacy of omnipotent, homogeneous beneficiaries. Ecol. Econ. 121, 175-180. 